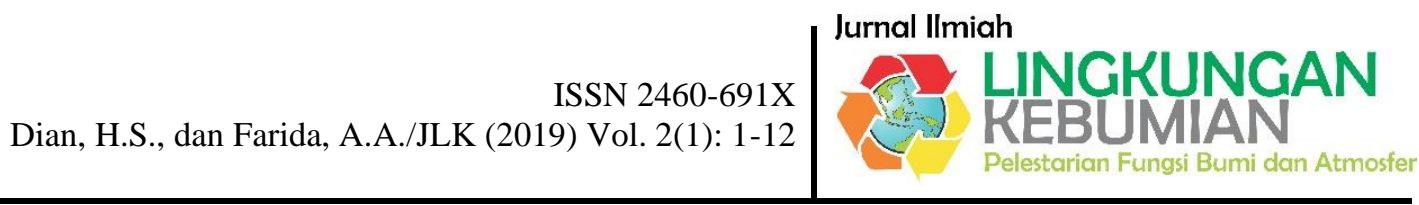

\title{
Valuasi Deplesi Sumberdaya Air dalam Rangka Penghitungan PDRB Semi Hijau di Kota Malang, Jawa Timur
}

\author{
Dian Hudawan Santoso dan Farida Afriani Astuti \\ Jurusan Teknik Lingkungan, Fakultas Teknologi Mineral, UPN "Veteran” Yogyakarta, \\ Jl. SWK 104 (Lingkar Utara), Condongcatur, Yogyakarta, 55283 \\ E-mail korespondensi: hudageo@gmail.com
}

\begin{abstract}
ABSTRAK
PDRB Hijau merupakan indeks baru yang digunakan untuk menghitung output dari perekonomian nasional dan daerah yang mempertimbangkan faktor lingkungan dalam perhitungannya. PDRB Semi hijau dihitung hanya dengan mempertimbangkan faktor deplesi sumber daya alam sedangkan PDRB Hijau mempertimbangkan deplesi dan degradasi sumber daya alam pada suatu daerah. Deplesi sumber daya alam menunjuk pada produksi, pengambilan, pengurasan, pengurangan volume atau jumlah sumberdaya alam. Penelitian ini bertujuan untuk menghitung nilai deplesi sumberdaya alam yang terdapat di Kota Malang yang merupakan salah satu kota besar di Provinsi Jawa Timur, sehingga pada akhirnya nanti dapat pula dihitung PDRB Semi Hijau yang merupakan bagian untuk menghitung nilai PDRB Hijau. Metode yang dipakai adalah metode survei dan pengamatan, studi literatur, pegukuran dan analisis metematis. Hasil yang didapatkan adalah berdasarkan identifikasi terhadap sumber daya alam di Kota Malang tidak ditemukan pengambilan volume sumber daya alam kecuali pada penggunaan sumber daya air. Berdasarkan data-data yang diperoleh hampir semua sektor ekonomi memanfaatkan sumber daya air untuk operasional kegiatannya. Objek lain yang diasumsikan juga terdeplesi ternyata tidak ditemukan di daerah penelitian. Berdasarkan analisis diketahui nilai deplesi penggunaan sumberdaya air menyerap sekitar 0,354 \% dari total nilai PDRB konvensional Kota Malang. Dengan demikian, nilai PDRB Semi Hijau Kota Malang dengan mempertimbangkan nilai deplesi sumber daya air mengalami penurunan -0,354\%.
\end{abstract}

Kata kunci: Deplesi; Kota Malang; PDRB Semi Hijau; Sumber daya air

\begin{abstract}
Green GRDP is a new index that is used to calculate the output of national and regional economies that take environmental factors into account. Semi-green GRDP is calculated only by considering the depletion factor of natural resources while Green GRDP considers depletion and degradation of natural resources in an area. Depletion of natural resources refers to the production, extraction, depletion, reduction in volume or amount of natural resources. This study aims to calculate the value of depletion of natural resources found in Malang, which is one of the major cities in East Java Province, so that in the end it can also be calculated Semi-Green GRDP which is part of calculating the value of Green GRDP. The method used is the method of surveying and observing, literature study, measurement and mathematical analysis. The results obtained are based on the identification of natural resources in the city of Malang, there is no volume extraction of natural resources found except on the use of water resources. Based on the data obtained almost all economic sectors utilize water resources for operational activities. Other objects that were assumed to be depleted were not found in the study area. Based on the analysis, it is known that the depletion value of using water resources absorbs around $0.354 \%$ of the total value of Malang City's conventional GRDP. Thus, the value of the Semi Green GRDP of Malang City by considering the depletion value of water resources decreased $-0.354 \%$.
\end{abstract}

Keywords: Depletion; Malang City; Semi-Green GRDP; Water resources

\section{PENDAHULUAN}

Secara konvensional PDRB (Produk Domestik Regional Bruto) dipergunakan untuk mengukur keberhasilan kinerja pembangunan suatu daerah (Kabupaten/Kota atau Propinsi). PDRB sebagai salah satu indikator dan alat ukur proses pembangunan dan kesejahteraan masyarakat suatu daerah selama ini 


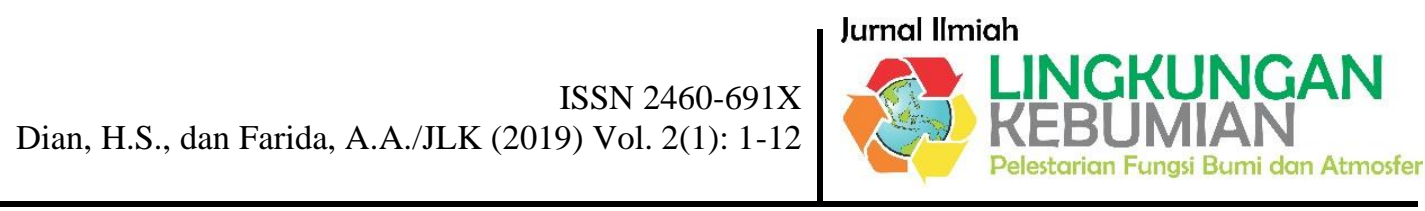

belum memasukkan unsur sumberdaya alam dan lingkungan alam dalam perhitungannya secara ekonomis (Waluyati et al., 2010).

Lahirnya konsep ekonomi hijau dapat menghasilkan kesejahteraan dan keadilan sosial umat manusia yang lebih baik, dan secara signifikan mengurangi resiko lingkungan dan kerusakan ekologis Program Lingkungan PBB (UNEP; United Nations Environment Programme) dalam laporannya berjudul Towards Green Economy menyebutkan, ekonomi hijau adalah ekonomi yang mampu meningkatkan kesejahteraan dan keadilan sosial. Ekonomi hijau ingin menghilangkan dampak negatif pertumbuhan ekonomi terhadap lingkungan dan kelangkaan sumber daya alam. Ekonomi Hijau dapat melengkapi konsep pembangunan berkelanjutan (sustainable development) (Maulana, 2013).

Hilangnya kualitas dan kuantitas sumberdaya alam yang mendorong ke arah deplesi dan degradasi lingkungan harus diperhitungkan dalam indikator pembangunan, tujuannya berkaitan dengan keberlanjutan atau kelestarian sumberdaya dan lingkungan serta akan lebih mencerminkan tingkat kesejahteraan masyarakat yang sesungguhnya. Selanjutnya PDRB yang belum memasukkan valuasi ekonomi sumberdaya dinamakan dengan PDRB Coklat atau Konvensional (Setyarko, 2018).

Berdasarkan kondisi diatas dibuatlah indikator ekonomi lain yang disebut dengan PDRB Hijau. PDRB Konvensional dirasa perlu dilengkapi dengan memperhitungkan jasa lingkungan dan penyusutan sumberdaya alam dan lingkungan, sehingga perlu dicari nilai PDRB Hijau atau PDRB Ramah Lingkungan (Suparmoko, 2008). PDRB Hijau merupakan indeks baru yang digunakan untuk menghitung output dari perekonomian nasional dan daerah yang mempertimbangkan faktor lingkungan dalam perhitungannya (Dicknison dalam Deviane, 2017).

Kota Malang, Provinsi Jawa Timur merupakan salah satu kota yang memiliki perkembangan yang sangat pesat. Perkembangan kota yang pesat sedikit banyak disebabkan oleh besarnya nilai pertumbuhan ekonomi setempat yang digambarkan dengan kondisi PDRB Kota Malang. Dengan demikian pertumbuhan tersebut mampu menyebabkan perubahan kondisi lingkungan atau sumberdaya alam terutama terjadinya deplesi dan degradasi lingkungan. Hal inilah yang menjadi fokus dalam penelitian ini dimana perlu dilakukan pengukuran PDRB Hijau untuk Kota Malang dengan tujuan mengetahui seberapa besar kesejahteraan masyarakat yang sesungguhnya. Untuk mencapai tahap pengukuran PDRB hijau harus melibatkan pengukuran deplesi ataupun degradasi lahan, karena masih terbatasnya data degradasi lingkungan sehingga dalam penelitian ini hanya dibatasi sampai menghasilkan nilai PDRB semi hijau saja.

\section{METODE PENELITIAN}

Lokasi penelitian ini dilakukan di Kota Malang. Pelaksanaan penelitian menggunakan 2 (dua) pendekatan, yaitu: (a) studi dokumen yang mencakup inventarisasi dokumen dan data perekonomian Kota Malang, laporan terkait aspek lingkungan, penelitian ilmiah dan berbagai jenis peraturan perundang-undangan terkait; dan (b) survey lapangan yang dilakukan dalam rangka memperoleh informasi untuk penghitungan jasa lingkungan, deplesi sumber daya alam/lingkungan dan degradasi sumberdaya alam/lingkungan yang digunakan dalam kegiatan usaha dari sektor - sektor usaha yang menjadi basis perekonomian Kota Malang. 


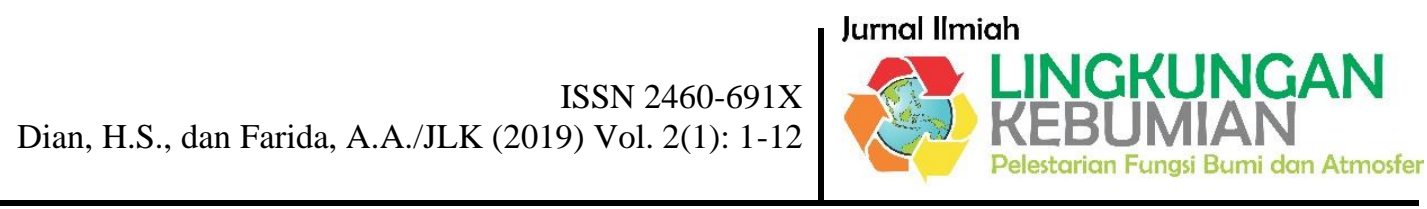

Pada penelitian ini menggunakan 2 jenis data yaitu data primer dan data sekunder. Data primer yaitu data yang diperoleh dari hasil pengamatan/pengukuran dan wawancara secara langsung di lapangan, sedangkan data sekunder adalah data yang didapatkan dari laporan-laporan resmi OPD - OPD terkait maupun hasil pembacaan dari literatur-literatur yang berkaitan dengan penelitian ini.

\section{A. Metode pengumpulan data}

Metode pengumpulan data pada penelitian ini adalah sebagai berikut :

1. Survei dan observasi.

Metode survei dan observasi dilakukan dengan cara melakukan survei secara langsung di lapangan untuk mengamati dan mengukur kondisi fisik sumber daya alam lingkungan. Kondisi fisik sumber daya alam lingkungan yang dimaksud adalah sumber daya alam yang mengalami deplesi dan degradasi yang terdapat di Kota Malang.

2. Wawancara.

Metode ini dilakukan dengan tujuan untuk mengetahui karakteristik masing - masing objek lingkungan hidup yang mengalami deplesi dan degradasi serta jasa lingkungan. Wawancara dilakukan terhadap responden yang terkait dalam pemanfaatan, penggunaan dan yang terdampak terhadap perubahan sumber daya alam lingkungan hidup di Kota Malang.

3. Studi literatur dan pencarian data dari instansi

Metode ini dilakukan untuk memperoleh data secara langsung dari instansi terkait yang berkaitan dengan penelitian ini. Data yang dicari dapat berupa laporan - laporan resmi yang di keluarkan oleh SKPD terkait.

\section{B. Metode Perhitungan Jasa Lingkungan}

1. Nilai Guna Langsung (NGL), untuk nilai karbon diperkirakan dengan harga voluntary sebesar US $\$ 5.00$; US $\$ 10.00$; US $\$ 15.00$ (Lumangkun et al, 2012).

2. Nilai Guna Tak Langsung (NGTL), Perhitungan manfaat ekonomi rekreasi digunakan konsep Willingness To Pay (WTP). Nilai kesediaan membayar/WTP diperoleh dengan cara wawancara menggunakan kuisioner kepada responden yang terdiri dari masyarakat sekitar dan pengunjung. Analisis nilai ekonomi keberadaan RTH dengan menggunakan pendekatan Contingent Valuation Method (CVM). Hal ini dikarenakan nilai keberadaan RTH tidak memiliki harga. Penerapan CVM dalam menentukan kesediaan membayar memiliki 5 tahapan menurut Hanley dan Spash (1993 dalam Aryanto dan Yuwana 2005).

\section{Metode Penghitungan PDRB Semi Hijau}

PDRB semi hijau adalah hasil pengembangan PDRB Coklat dengan memasukan dimensi lingkungan (deplesi SDA dan kerusakan lingkungan) kedalam perhitungan PDRB Coklat atau Konvensional. PDRB semi hijau didapat dengan mengurangkan nilai deplesi sumber daya alam dari nilai PDRB Konvensional (atau PDRB Coklat). Nilai deplesi diperoleh dengan mengalikan volume pengambilan masing-masing ienis sumherdaya alam dengan unit rent atau unit nrice (Rumus 1).

Nilai produksi

Input Perantara (Intermediet Inputs)

Nilai Tambah (PDRB) Coklat

Deplesi SDA

PDRB Semi Hijau
Rp.......

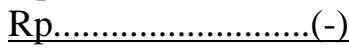

$\mathrm{Rp}$.

Rp........................(-)

Rp. 


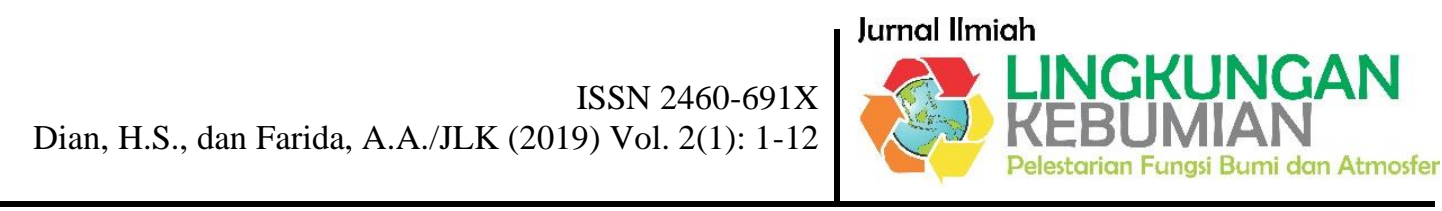

Cara menghitung unit rent adalah dengan mengurangkan biaya pengambilan per unit dari harga sumber daya alam termasuk nilai laba per unit (balas jasa pengeluaran investasi) yang layak diterima oleh investor. Adapun nilai laba yang layak adalah sama dengan tingkat bunga pinjaman di bank sebagai biaya alternatif dari modal yang ditanam untuk mengeksploitasi sumber daya alam di daerah yang bersangkutan. Cara perhitungan unit rent adalah sesuai dengan Persamaan 2 berikut.

Unit Rent $=($ Harga Produk $)-($ Rata-rata Biaya Produksi $)-($ Rata-rata Laba Layak Per Unit Rent $)$

Nilai Ekonomi Jasa Lingkungan juga dapat diintegrasikan atau dimasukkan dalam penghitungan ke dalam PDRB Semi Hijau. Nilai Ekonomi Jasa Lingkungan memberikan gambaran nilai tambah kontribusi lingkungan terhadap nilai total dari PDRB Semi Hijau berdasarkan Rumus 3 berikut.

\begin{tabular}{|c|c|}
\hline Nilai produksi & $\mathrm{Rp}$ \\
\hline Input Perantara (Intermediet Inputs) & Rp................................ \\
\hline Nilai Jasa Lingkungan & 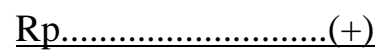 \\
\hline Nilai Tambah (PDRB) Coklat & $\mathrm{Rp}$ \\
\hline Deplesi SDA & Rp............................ \\
\hline PDRB Semi Hijau & Rp.. \\
\hline
\end{tabular}

\section{HASIL DAN PEMBAHASAN}

Deplesi sumber daya alam dan lingkungan menunjuk pada produksi, pengambilan, pengurasan, pengurangan volume atau jumlah sumberdaya alam. Berdasarkan identifikasi terhadap sumber daya alam dan lingkungan di Kota Malang tidak ditemukan pengambilan volume sumber daya alam kecuali pada penggunaan sumber daya air. Berdasarkan data-data yang tersedia dan fakta lapangan hampir semua sektor ekonomi memanfaatkan sumber daya air untuk operasional kegiatannya. Objek lain yang diasumsikan juga terdeplesi ternyata tidak ditemukan di daerah penelitian seperti kegiatan penambangan dan penebangan atau kehilangan pohon pada hutan-hutan kota secara masif. Oleh karena itu ditentukanlah penggunaan sumber daya air di Kota Malang sebagai faktor utama penghasil nilai deplesi dalam perhitungan PDRB Hijau.

\section{A. Perhitungan Volume Sumber Daya Air yang Terdeplesi di Kota Malang} 1. Sektor Pertanian, Kehutanan dan Perikanan

Penggunaan air pada sektor pertanian dirinci berdasarkan ketersediaan data standar penggunaan air dari SNI 19-6728.1-2002 tentang Penyusunan Neraca Sumber Daya - Bagian 1: Sumber daya air spasial. Berdasarkan data tersebut, penggunaan air yang dapat dihitung adalah pada sub sektor Tanaman Bahan Makanan, Peternakan, dan Perikanan.

\section{a. Tanaman Bahan Makanan}

Nilai deplesi air pada sub sektor Tanaman Bahan Makanan menggunakan dasar perhitungan SNI 196728.1-2002 bahwa standar kebutuhan air rata-rata adalah 1 liter/detik/Ha baik untuk irigasi teknis, semi teknis, maupun irigasi sederhana. Jumlah hari yang diperlukan untuk menanam padi adalah 120 hari. Tanaman bahan makanan pada Kota Malang yaitu sawah dan tegal/kebun. Nilai deplesi air pada sub sektor Tanaman Bahan Makanan (TBM) ditentukan berdasarkan Persamaan 4 berikut. 


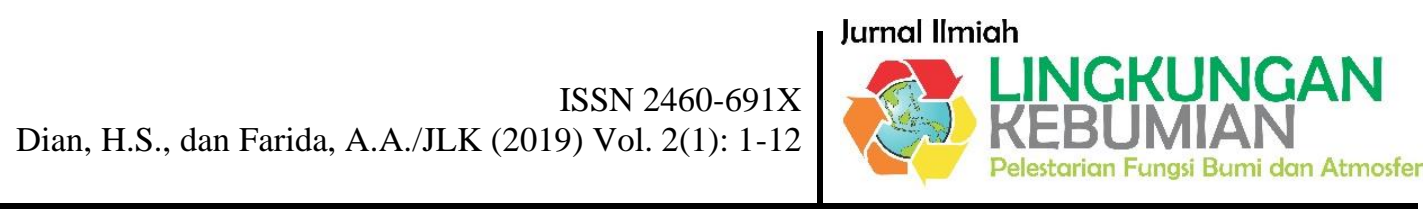

$\mathrm{V}$ TBM = Luas (Ha) x 1 liter/dtk/Ha x 3600 dtk x 24 jam x 120 hari

Sehingga, total volume penggunaan air untuk tanaman bahan makanan adalah 28.086.912.000 liter per tahun

\section{b. Peternakan}

Volume penggunaan air pada sub sektor peternakan dihitung berdasarkan jumlah jenis ternak dengan standar kebutuhan air untuk masing-masing jenis ternak acuan dari SNI 19-6728.1-2002. Berdasarkan data BPS, ternak di Kota Malang yaitu sapi potong, sapi perah, kerbau, kuda, kambing, domba, kelinci, ayam kampung, ayam petelur, ayam pedaging, itik, itik manila, puyuh dan merpati. Nilai deplesi air pada sub sektor peternakan ditentukan berdasarkan pada Persamaan 5 berikut.

$$
\text { V Peternakan }=\text { Jumlah masing }- \text { masing ternak } x 40 \text { liter/hari } x 365 \text { hari }
$$

Hasil yang diperoleh terkait dengan volume penggunaan air peternakan sebesar 230.151.699 liter per tahun.

\section{c. Perikanan}

Volume penggunaan air pada sub sektor perikanan dihitung berdasarkan jumlah luas lahan kolam tambak dengan standar penggunaan air tawar untuk masing-masing jenis kolam tambak dengan standar kebutuhan air tambak menggunakan acuan dari SNI 19-6728.1-2002. Penggunaan air diperhitungkan dalam 1 tahun terdiri atas 2 musim dengan total 150 hari. Nilai deplesi air pada sub sektor perikanan ditentukan berdasarkan Persamaan 6 berikut.

V Perikanan = Luas $(\mathrm{Ha}) \times 4.91$ liter/dtk/Ha x 3600 dtk x 24 jam x 150 hari

Hasil yang diperoleh terkait dengan volume penggunaan air untuk perikanan sebesar 157.174.992 liter per tahun.

\section{Sektor Industri Pengolahan}

Volume penggunaan air pada sektor industri didasarkan pada data volume air yang disalurkan oleh PDAM ke industri yaitu sebesar $8387 \mathrm{~m}^{3}$ atau sebesar 8.387 .000 liter per tahun 2017 (BPS Kota Malang Dalam Angka, 2018).

\section{Sektor Pengadaan Air, Pengelolaan Sampah, Limbah dan Daur Ulang}

Pengadaan air dihitung berdasarkan data volume air yang disalurkan oleh PDAM di Kota Malang ke rumah tangga dan khusus, yaitu sebesar 33.167.730.495 liter di tahun 2017 (PDAM Kota Malang, 2018).

\section{Sektor Perdagangan}

Volume penggunaan air pada sub sektor perdagangan didasarkan pada data volume air yang disalurkan oleh PDAM sebesar 1.250,532 $\mathrm{m}^{3}$ atau sebesar 1.250.532 liter pada tahun 2017 (BPS Kota Malang Dalam Angka, 2018). 


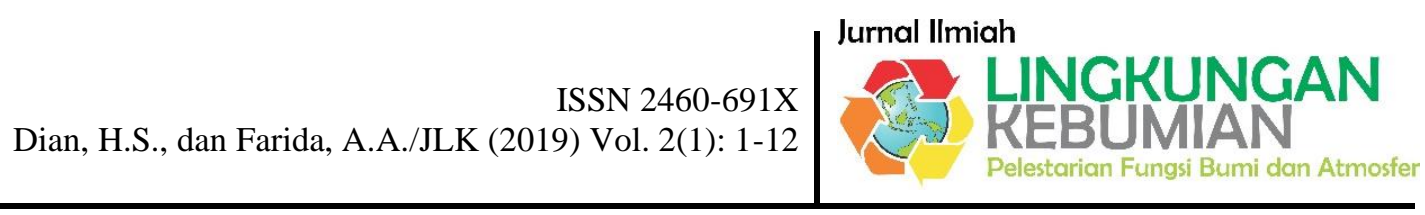

\section{Sektor Penyediaan Akomodasi dan Makan Minum}

Penghitungan volume sumber daya air pada sektor ini terdiri dari 2 bagian yaitu sub hotel dan restoran dengan perincian volume deplesi sebagai berikut.

\section{a. Hotel}

Volume penggunaan air pada sub sektor Hotel terdiri dari penggunaan air oleh pengunjung hotel dan penggunaan air oleh karyawan. Untuk memperoleh volume penggunaan air oleh tenaga kerja didasarkan dari jumlah tenaga kerja pada sektor hotel dikalikan dengan kebutuhan air per orang per hari dengan acuan SNI 19-6728.1-2002. Sementara, pada penghitungan penggunaan air oleh pengunjung hotel dihitung dari jumlah tempat tidur hotel di Kota Malang dikali dengan persentase tingkat hunian dikalikan dengan standar baku kebutuhan air untuk tamu hotel per tempat tidur per hari dengan acuan SNI 196728.1-2002. Persamaan 7, 8, dan 9 berikut digunakan untuk menentukan nilai deplesi air pada sub sektor hotel :

$$
\begin{array}{ll}
\mathrm{V} \mathrm{TKH} & =\Sigma \mathrm{TK} \times 120 \text { liter/hari } \mathrm{x} 365 \text { hari } \\
\mathrm{V} \mathrm{PH} & =\Sigma \mathrm{Kt} \times \% \mathrm{PK} \times 90 \text { liter/harix365 hari } \\
\mathrm{V} \mathrm{dH} & =\mathrm{V} \mathrm{TKH}+\mathrm{V} \mathrm{PH}
\end{array}
$$

\begin{tabular}{|c|c|}
\hline Keterangan & \\
\hline V TKH & : V Tenaga Kerja Hotel \\
\hline$\Sigma \mathrm{TK}$ & : Jumlah tenaga kerja \\
\hline V PH & : V Pengunjung Hotel \\
\hline$\Sigma \mathrm{Kt}$ & : Jumlah Kamar tersedia \\
\hline$\% \mathrm{PK}$ & : Persentase Kunjungan \\
\hline V DepH & : Volume deplesi air sektor hotel \\
\hline
\end{tabular}

Hasil perhitungan volume deplesi air oleh tamu hotel di tahun 2017 adalah 74.521.402,13 liter per tahun. b. Restoran

Volume penggunaan air pada sub sektor restoran dan rumah makan terdiri dari penggunaan air oleh pengunjung restoran dan rumah makan dan penggunaan air oleh karyawan. Untuk memperoleh volume penggunaan air oleh tenaga kerja didasarkan dari jumlah tenaga kerja pada sektor restoran dan rumah makan dikalikan dengan kebutuhan air per orang per hari dengan acuan SNI 19-6728.1-2002. Sementara, pada penghitungan penggunaan air oleh pengunjung restoran dan rumah makan dihitung dari jumlah kursi restoran dan rumah makan di Kota Malang dikali dengan persentase tingkat kunjungan dikalikan dengan standar baku kebutuhan air untuk restoran dan rumah makan per tempat duduk per

\begin{tabular}{|c|c|}
\hline V TKRM & $=\Sigma \mathrm{TK} \times 120$ 1/hari $\times 365$ \\
\hline V PRM & $=\Sigma \mathrm{Kt} \times \% \mathrm{PK} \times 100$ l/hari $\times 365$ hari \\
\hline V Dep. & =V TKRM+V PRM \\
\hline Keter & \\
\hline$\Sigma \mathrm{TK}$ & : Jumlah tenaga kerja \\
\hline & : V Pengunjung restoran dan rumah makan \\
\hline
\end{tabular}
hari dengan acuan Standar Kebutuhan Air Minum (PU Cipta Karya, 1998). Nilai deplesi air pada sub sektor restoran dan rumah makan ditentukan berdasarkan Persamaan 10, 11, dan 12. 


$\begin{array}{ll}\Sigma \mathrm{Kt} & : \text { Jumlah Kamar tersedia } \\ \text { \%PK } & : \text { Persentase pengunjung } \\ \text { V DepRM } & : \text { Volume deplesi air sektor restoran dan rumah makan } \\ \text { V TKRM } & : \text { V Tenaga kerja restoran dan rumah makan } \\ \text { V PRM } & : \text { V Pengunjung restoran dan rumah makan }\end{array}$

Hasil perhitungan volume deplesi air oleh pengunjung restoran dan rumah makan di tahun 2017 adalah 37.126.405,7 liter per tahun.

\title{
6. Sektor Transportasi dan Pergudangan
}

Volume penggunaan air pada sektor transportasi dan pergudangan dilakukan pada sub sektor transportasi (angkuta penumpang, bus dan truk). Penggunaan air oleh angkutan umum dihitung berdasarkan Persamaan 13.

$\mathrm{V} \mathrm{TP}=\Sigma \mathrm{X}_{\mathrm{k}} \mathrm{x} 150$ liter/harix365 harix24 kali/tahun

\author{
Keterangan: \\ V TP :V Transportasi dan Pergudangan \\ $\Sigma \mathrm{X}_{\mathrm{k}} \quad$ : Jumlah Kendaraan
}

Frekuensi cuci kendaraan di asumsikan setiap kendaraan dicuci 2 kali dalam sebulan sehingga dalam 1 tahun adalah 24 kali. Data mengenai jumlah kendaraan umum diperoleh dari Kota Malang dalam Angka, BPS 2018. Standar baku kebutuhan air yang digunakan adalah standar sambungan rumah yang mengacu pada Standar Kebutuhan Air Minum (PU Cipta Karya, 1998). Volume deplesi air pada sektor transportasi di tahun 2017 sebesar 310.852.800 liter/tahun.

\section{Sektor Jasa Keuangan dan Asuransi}

Pada sektor Keuangan, Persewaan dan Jasa Perusahaan, pengambilan data survey sekunder dilakukan pada sektor jasa keuangan (perbankan). Ketersediaan data sekunder kurang memadai terkait informasi mengenai sub sektor persewaan dan jasa perusahaan. Dengan demikian, perhitungan deplesi air dilakukan berdasarkan hasil survey data sekunder pada sektor perbankan pada BPS Kota Malang dalam Angka (2018). Sektor bank tersebut yaitu bank pemerintahan, bank pemerintahan daerah, bank swasta, bank konvensional, bank Syariah, bank devisa pemerintah, bank devisa BPD, bank non devisa BPD, bank devisa swasta dan bank non devisa swasta. Nilai deplesi air pada sub sektor Keuangan, Persewaan dan Jasa Perusahaan ditentukan berdasarkan Persamaan 14 dan 15.

$\mathrm{V} \operatorname{DepB}=\Sigma \mathrm{X}_{\mathrm{b}} \mathrm{x}$ VPBx365 hari

dimana, $(\mathrm{VPB}=\mu / \Sigma \mathrm{X})$

Keterangan :

V DepB : Volume Air Deplesi Bank

$\Sigma X_{\mathrm{b}} \quad$ :Jumlah Bank

VPB : Volume Per Bank (liter)

$\mu \quad$ : Rata-rata penggunaan air bank

$\Sigma \mathrm{X}$ : Jumlah bank. 
Volume deplesi air pada sektor perbankan di tahun 2017 sebesar 932.999.398,4 liter per tahun.

\section{Sektor Administrasi Pemerintahan, Pertahanan dan Jaminan Sosial Wajib}

Volume deplesi air pada sektor Administrasi Pemerintah diperoleh berdasarkan ketersediaan data sekunder berupa volume air yang disalurkan PDAM ke Instansi Pemerintah sebesar 609.855 liter per tahun 2017 (BPS Kota Malang Dalam Angka, 2018).

\section{Sektor Jasa Kesehatan dan Kegiatan Sosial}

Volume deplesi air pada sektor Sosial Kemasyarakatan diperoleh berdasarkan ketersediaan data sekunder berupa volume air yang disalurkan PDAM ke sektor Sosial sebesar 1.286.787 liter per tahun 2017 (BPS Kota Malang Dalam Angka, 2018).

\section{Sektor Jasa Lainnya}

Volume deplesi air pada sektor jasa lainnya (Hiburan dan Rekreasi) diperoleh berdasarkan data sekunder rekreasi. Penggunaan air pada tempat rekreasi dihitung dari jumlah tempat rekreasi dikalikan dengan standar pemakaian air Kawasan parawisata yang acuannya dari Kriteria Perencanaan Ditjen Cipta Karya PU, 1996. Nilai deplesi air pada sub sektor rekreasi ditentukan berdasarkan Persamaan 16.

$\mathrm{VR}=\Sigma \mathrm{r} \times 0,3$ liter/detik $\times 3.600$ detik $\times 24$ jam $\times 365$ hari

Keterangan:

VR : Volume Rekreasi

$\Sigma \mathrm{r} \quad$ : Jumlah rekreasi

Volume pemakaian air pada sub sektor Rekreasi sebesar 104.068.800 liter per tahun.

Tabel 1. Volume Pemakaian Air Tahunan per Sektor

\begin{tabular}{lr}
\hline \multicolumn{1}{c}{ Lapangan Usaha } & $\begin{array}{c}\text { Volume Pemakaian Air } \\
\text { (Liter/tahun) }\end{array}$ \\
\hline Pertanian, Kehutanan dan Perikanan & 28.474 .238 .691 \\
Pertambangan dan Penggalian & - \\
Industri Pengolahan & 8.387 .000 \\
Pengadaan Listrik dan Gas & - \\
Pengadaan Air, Pengadaan Sampah, Limbah dan & 33.167 .730 .495 \\
Daur Ulang & - \\
Konstruksi & 1.250 .532 \\
Perdagangan Besar dan Eceran, Reparasi Mobil & 310.852 .800 \\
dan Sepeda Motor & $111.647 .807,8$ \\
Transportasi dan Pergudangan & - \\
Penyediaan Akomodasi dan Makan Minum & $932.999 .398,4$ \\
Informasi dan Komunikasi & - \\
Jasa Keuangan dan Asuransi & - \\
Real Estate & 609.855 \\
Jasa Perusahaan & \\
Adiministrasi Pemerintah, Pertahanan dan & - \\
Jaminan Sosial Wajib & 1.286 .787 \\
Jasa Pendidikan & 104.068 .800 \\
\hline Jasa Kesehatan dan Kegiatan Sosial &
\end{tabular}




\section{B. Perhitungan Unit Rent Sumber Daya Air di Kota Malang}

Setelah diperoleh hasil perhitungan volume deplesi air diatas, langkah selanjutnya adalah melakukan konversi volume deplesi air tersebut ke dalam satuan moneter. Untuk itu diperlukan satuan unit rent. Pendekatan yang digunakan dalam menghitung unit rent adalah Harga Dasar Air sebagaimana diatur dalam Peraturan Bupati Malang No. 59 Tahun 2012 tentang Perhitungan Nilai Perolehan Air Tanah dan Peraturan Walikota Malang No. 39 Tahun 2014 tentang Penetapan Tarif Air Minum dan Biaya Langganan pada PDAM Kota Malang.

\section{Nilai Deplesi Sumber Daya Air di Kota Malang}

Setelah diketahui volume sumber daya air yang terdeplesi dan unit rent dari sumber daya air, maka nilai deplesi sumber daya air dapat dihitung dalam satuan moneter. Perhitungan nilai moneter deplesi adalah sesuai Tabel 4. Nilai deplesi sumber daya air diperoleh dari sektor pertanian, sektor industri, sektor gas, listrik dan air bersih, sektor perdagangan, hotel dan restoran, sektor angkutan dan komunikasi, sektor keuangan, persewaan dan jasa perusahaan, serta sektor jasa-jasa. Pada sektor lainnya seperti pertambangan dan bangunan berdasarkan data BPS tidak ditemukan eksploitasi sumber daya air. Berdasarkan pengolahan data sebagaimana ditunjukkan dalam Tabel 4 diketahui sektor yang menyumbangkan nilai terbesar adalah dari sektor pengadaan air, pengadaan sampah, limbah dan daur ulang dengan volume penggunaan air sebesar 33.167.730.495 liter/tahun sehingga menghasilkan nilai Rp 186.401.117.358,- Nilai deplesi total akibat penggunaan sumber daya air dari berbagai sektor adalah Rp 220.540.564.966,-

Tabel 4. Deplesi Per Sektor Usaha di Kota Malang

\begin{tabular}{|c|c|c|c|c|c|}
\hline Lapangan Usaha & $\begin{array}{c}\text { Volume } \\
\text { Pemakaian } \\
\text { Air } \\
\text { (Liter/tahun) }\end{array}$ & $\begin{array}{c}\text { Volume } \\
\text { Pemakaian Air } \\
\left(\mathbf{m}^{3} / \text { tahun }\right)\end{array}$ & $\begin{array}{c}\text { Kelompok } \\
\text { Pelanggan } \\
\text { (Tarif Air } \\
\text { Minum) }\end{array}$ & $\begin{array}{c}\text { Tarif } \\
\text { Air } \\
\text { Minum } \\
\left(\mathbf{R p} / \mathbf{m}^{3}\right)\end{array}$ & $\begin{array}{c}\text { Deplesi } \\
\text { (Rp/tahun) }\end{array}$ \\
\hline $\begin{array}{l}\text { Pertanian, Kehutanan dan } \\
\text { Perikanan }\end{array}$ & $\begin{array}{r}28.474 .238 .69 \\
1\end{array}$ & $28.474 .238,691$ & $\begin{array}{r}\text { Non niaga } \\
\text { bukan mata air }\end{array}$ & 518 & 14.749 .655 .642 \\
\hline $\begin{array}{l}\text { Pertambangan dan Penggalian } \\
\text { Industri Pengolahan }\end{array}$ & $8.387 .000^{-}$ & 8.387 & Industri & $15.300^{-}$ & $128.321 .100^{-}$ \\
\hline Pengadaan Listrik dan Gas & - & - & - & - & - \\
\hline $\begin{array}{l}\text { Pengadaan Air, Pengadaan } \\
\text { Sampah, Limbah dan Daur Ulang }\end{array}$ & $\begin{array}{r}33.167 .730 .49 \\
5\end{array}$ & $33 \cdot 167.730,495$ & $\begin{array}{r}\text { - Rumah } \\
\text { Tangga } \\
\text { - Khusus }\end{array}$ & $\begin{array}{r}-5.620 \\
-518\end{array}$ & 186.401.117.358 \\
\hline Konstruksi & - & - & - & - & - \\
\hline $\begin{array}{l}\text { Perdagangan Besar dan Eceran, } \\
\text { Reparasi Mobil dan Sepeda } \\
\text { Motor }\end{array}$ & 1.250 .532 & $1.250,532$ & Niaga & 10.400 & $13.005 .532,8$ \\
\hline Transportasi dan Pergudangan & 310.852 .800 & $310.852,8$ & Sosial & 2.800 & 870.387 .840 \\
\hline $\begin{array}{l}\text { Penyediaan Akomodasi dan } \\
\text { Makan Minum }\end{array}$ & $111.647 .807,8$ & 111647,8078 & Niaga A & 10.400 & 1.161.137.201 \\
\hline Informasi dan Komunikasi & - & - & - & - & - \\
\hline Jasa Keuangan dan Asuransi & 932.999.398,4 & $932.999,3984$ & Niaga D & 17.300 & 16.140 .889 .593 \\
\hline Real Estate & - & - & - & - & - \\
\hline Jasa Perusahaan & - & - & - & - & - \\
\hline $\begin{array}{l}\text { Adiministrasi Pemerintah, } \\
\text { Pertahanan dan Jaminan Sosial } \\
\text { Wajib }\end{array}$ & 609.855 & 609,855 & Instansi B & 6.200 & 3.781 .101 \\
\hline Jasa Pendidikan & - & - & - & - & - \\
\hline $\begin{array}{l}\text { Jasa Kesehatan dan Kegiatan } \\
\text { Sosial }\end{array}$ & 1.286 .787 & $1.286,787$ & Sosial & 2.300 & $2.959 .610,1$ \\
\hline Jasa Lainnya (Rekreasi) & 104.068 .800 & $104.068,800$ & Niaga A & 10.400 & 1.082 .315 .520 \\
\hline
\end{tabular}

Sumber : BPS Kota Malang Dalam Angka, 2018; Peraturan Bupati Malang No. 59 Tahun 2012; Peraturan Walikota Malang No 39 tahun 2014; Analisis Data, 2018. 


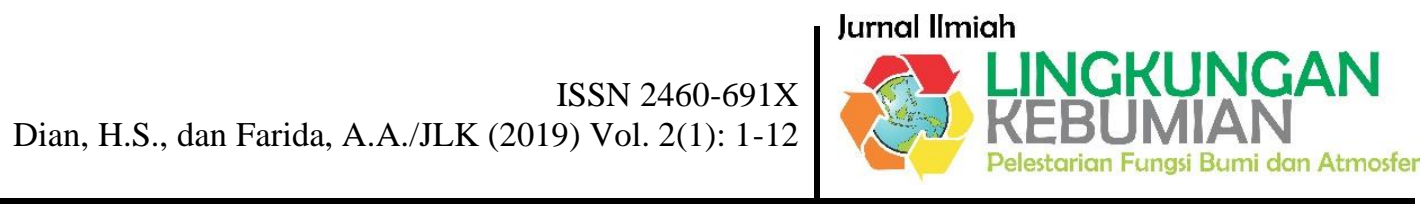

\section{PDRB Semi Hijau Kota Malang}

Nilai PDRB Semi Hijau diperoleh dari penjumlahan PDRB Coklat dengan Nilai Total Ekonomi Jasa Lingkungan, kemudian dikurangi dengan nilai total deplesi sumber daya air (Persamaan 17).

PDRB Semi Hijau = PDRB Coklat+Nilai Total Ekonomi Manfaat Jasa Lingkungan -Nilai Total Deplesi SDA

Nilai total ekonomi manfaat jasa lingkungan dalam penelitian ini tidak dilakukan sehingga memiliki nilai $\mathrm{Rp} 0,-$, kemudian berdasarkan analisis dan perhitungan diketahui nilai total deplesi dari sumber daya air adalah Rp 220.540.564.966,-. Diketahui nilai PDRB Coklat atas dasar harga berlaku pada tahun 2017 adalah sebesar Rp 62.359.303.700.000,- sehingga diketahui pula nilai PDRB Semi Hijau kota Malang adalah:

PDRB Semi Hijau kota Malang= Rp 62.359.303.700.000,- + Rp 0,- - Rp 220.540.564.966,$=\operatorname{Rp} 62.138 .763 .135 .034,-$

Tabel 5. PDRB Semi Hijau Tahun 2017

\begin{tabular}{|c|c|c|c|}
\hline Lapangan Usaha & $\begin{array}{l}\text { PDRB Konvensional } \\
(\mathbf{R p})\end{array}$ & $\begin{array}{l}\text { Deplesi Air } \\
\text { (Rp/tahun) }\end{array}$ & PDRB Semi Hijau (Rp) \\
\hline Pertanian, Kehutanan dan Perikanan & 168.603 .000 .000 & 14.749 .655 .642 & 153.853 .344 .358 \\
\hline Pertambangan dan Penggalian & 50.799 .400 .000 & - & 50.799 .400 .000 \\
\hline Industri Pengolahan & 15.663.754.000.000 & 128.321 .100 & 15.663.625.678.900 \\
\hline Pengadaan Listrik dan Gas & 20.637.400.000 & - & 20.637.400.000 \\
\hline $\begin{array}{l}\text { Peng Air, Peng Sampah, Limbah \& Daur } \\
\text { Ulang }\end{array}$ & 116.180 .700 .000 & 186.401.117.358 & -70.220 .417 .358 \\
\hline Konstruksi & 8.113 .244 .500 .000 & - & 8.113 .244 .500 .000 \\
\hline $\begin{array}{l}\text { Perdagangan Besar dan Eceran, Reparasi } \\
\text { Mobil dan Sepeda Motor }\end{array}$ & 18.456.646.700.000 & $13.005 .532,8$ & 18.456.633.694.467 \\
\hline Transportasi dan Pergudangan & 1.596.290.400.000 & 870.387 .840 & 1.595 .420 .012 .160 \\
\hline Penyediaan Akomodasi dan Makan Minum & 3.114 .800 .700 .000 & 1.161.137.201 & 3.113.639.562.799 \\
\hline Informasi dan Komunikasi & 2.501.653.000.000 & - & 2.501.653.000.000 \\
\hline Jasa Keuangan dan Asuransi & 1.858.208.800.000 & 16.140.889.593 & 1.842.067.910.407 \\
\hline Real Estate & 864.869 .200 .000 & - & 864.869 .200 .000 \\
\hline Jasa Perusahaan & 486.310 .500 .000 & - & 486.310 .500 .000 \\
\hline $\begin{array}{l}\text { Adiministrasi Pemerintah, Pertahanan dan } \\
\text { Jaminan Sosial Wajib }\end{array}$ & 903.995 .600 .000 & 3.781 .101 & 903.991 .818 .899 \\
\hline Jasa Pendidikan & 5.112 .782 .900 .000 & - & 5.112 .782 .900 .000 \\
\hline Jasa Kesehatan dan Kegiatan Sosial & 1.595 .400 .500 .000 & 2.959.610,1 & 1.595.397.540.390 \\
\hline Jasa Lainnya & 1.735 .134 .800 .000 & 1.082 .315 .520 & 1.734 .052 .484 .480 \\
\hline Jumlah & 62.359.303.700.000 & 220.540 .564 .966 & 62.138.758.529.502 \\
\hline
\end{tabular}

Sumber : PDRB BPS Kota Malang, 2017; Analisis Data, 2018

Nilai deplesi penggunaan sumber daya air menyerap sekitar 0,354 \% dari total nilai PDRB konvensional Kota Malang. Dengan demikian, nilai PDRB Semi Hijau Kota Malang dengan mempertimbangkan nilai deplesi sumber daya air dan tanpa mempertimbangkan nilai manfaat jasa lingkungan mengalami penurunan $-0,354 \%$ (Gambar 1). 


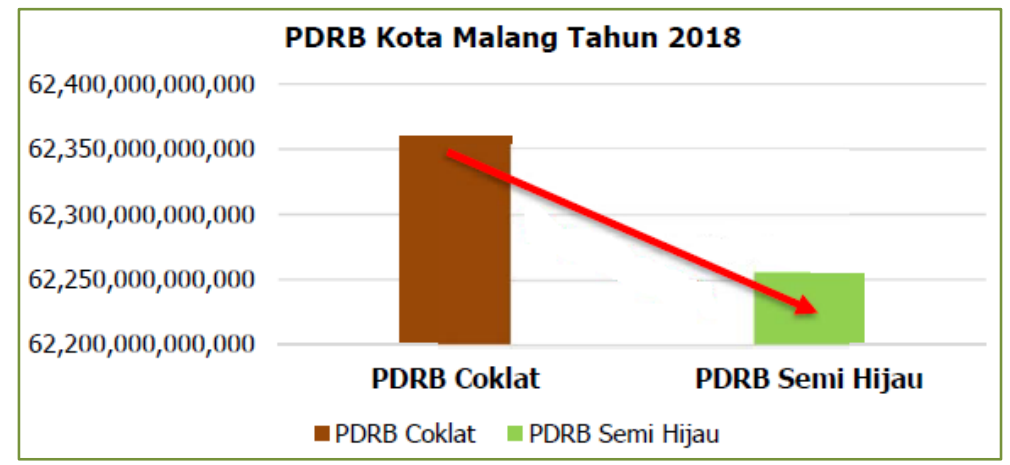

Gambar 1. Grafik Perbandingan PDRB Coklat, Semi Hijau, dan Hijau

\section{KESIMPULAN}

Berdasarkan identifikasi terhadap sumber daya alam dan lingkungan di Kota Malang tidak ditemukan pengambilan volume sumber daya alam kecuali pada penggunaan sumber daya air. Berdasarkan datadata yang tersedia dan fakta lapangan hampir semua sektor ekonomi memanfaatkan sumber daya air untuk operasional kegiatannya. Objek lain yang diasumsikan juga terdeplesi ternyata tidak ditemukan di daerah penelitian seperti kegiatan penambangan dan penebangan atau kehilangan pohon pada hutanhutan kota secara masif. Berdasarkan analisis diketahui nilai deplesi penggunaan sumberdaya air menyerap sekitar 0,354 \% dari total nilai PDRB konvensional Kota Malang. Dengan demikian, nilai PDRB Semi Hijau Kota Malang dengan mempertimbangkan nilai deplesi sumber daya air dan tanpa mempertimbangkan nilai manfaat jasa lingkungan mengalami penurunan $-0,354 \%$.

\section{DAFTAR PUSTAKA}

Aryanto, R., dan Yuwana, M. (2005). Valuasi Ekonomi dengan Travel Cost Method pada Obyek Ekowisata Pesisir, Jurnal Ilmiah Pariwisata, Vol. 10(1):58 - 76.

Badan Pusat Statistik. (2018). Statistik Derah Kota Malang 2018. BPS Kota Malang.

Deviane, A. (2017). Estimasi PDRB Hijau Jawa Barat 2011-2015. Bandung : Universitas Katolik Parahyangan Fakultas Ekonomi Program Sarjana Ekonomi Pembangunan.

Lumangkun, A., Hardiansyah G., Lidiawati I., Haryani UN., Ratih. (2012). Potensi Ekonomi Kayu Pada Arboretum Fakultas Kehutanan Universitas Tanjung Pura.

Maulana, R. (2016). Menghitung PDRB Hijau di Kabupaten Bandung. Bandung : Institut Teknologi Bandung (Seminar Nasional Inovasi dan Aplikasi Teknologi di Induatri (SENIATI) 2016 ISSN : 2085-4218.

Peraturan Pemerintah No. 82 Tahun 2001 tentang Pengelolaan Kualitas Air dan Pengendalian Pencemaran.

Setyarko, Y. (2018). Perhitungan PDRB Hijau Kota Bekasi, Jurnal Ekonomika dan Manajeman, Vol. 7 (1) April 2018: 28 - 42. 


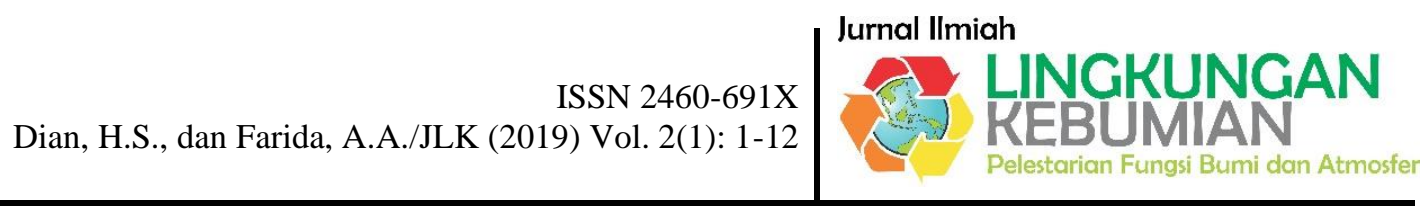

Suparmoko, M. (2008). Kontribusi Sektor Kehutanan Pada Pembangunan Daerah Kabupaten Blora. Blora : Fakultas Ekonomi Universitas Budi Luhur, Jurnal Ekonomi Pembangunan, Vol. 13(3) Desember 2008: 217-229.( Diakses pada Kamis, 4 Oktober 2018 pukul 23.41 WIB).

Waluyati, S. R., Any, S., Herman,M., Laurentius, H.M., dan Norbertus, C. I. (2010). Produk Domestik Regional Bruto (PDRB) Hijau Sektor Pertanian di Kabupaten Jayapura. Jurnal Agro Ekonomi, Vol. 17(2) Desember 2010: 123-130. 